\title{
Production and Verification of Hydrangea macrophylla $\times$ H. angustipetala Hybrids
}

\author{
Joshua H. Kardos ${ }^{1}$ \\ Department of Horticulture, University of Georgia, 1111 Plant Sciences, \\ Athens, GA 30602
}

Carol D. Robacker ${ }^{2}$

Department of Horticulture, University of Georgia, 1109 Experiment Street, Griffin, GA 30223

Michael A. Dirr ${ }^{1}$
Department of Horticulture, University of Georgia, 1111 Plant Sciences,
Athens, GA 30602

Timothy A. Rinehart

USDA-ARS, Southern Horticultural Laboratory, Poplarville, MS 39470

Additional index words. interspecific hybridization, pollen viability, simple sequence repeat, 'Lady in Red', Midnight Duchess ${ }^{\circledR}$ Abstract. The genetic diversity among $H$. macrophylla (Thunberg) Seringe taxa is limited
as a result of the restricted native distribution and multiple breeding programs that used
the same taxa and targeted similar breeding goals. This study assessed the compatibility
of interspecific crosses between $H y$ drangea macrophylla and $H$. angustipetala Hayata as a
source of genetic diversity. Two lacecap cultivars of $H$. macrophylla, 'Lady in Red' and
Midnight Duchess ${ }^{\circledR}$ ('HYMMAD II'), were compatible with $H$. angustipetala. Hybridity
of progeny was confirmed by simple sequence repeat markers and morphological
comparisons. Some hybrids had red- or purple-pigmented stems, which are character-
istic of 'Lady in Red' or Midnight Duchess ${ }^{\circledR}$, respectively. All hybrids had white lacecap
inflorescences. Some of the hybrid flowers were fragrant. Winter leaf retention of the
hybrids ranged from deciduous to semievergreen. Male fertility of progeny was
evaluated by fluorescein diacetate staining of pollen. 'Lady in Red', Midnight Duchess ${ }^{\circledR}$,
and $H$. angustipetala had $62 \%, 58 \%$, and $79 \%$ stainable pollen, respectively, whereas the
'Lady in Red' $\times H$. angustipetala and Midnight Duchess ${ }^{\circledR} \times H$. angustipetala hybrids had
means of $48 \%$ and $47 \%$ stainable pollen, respectively. Selected progeny were used to
develop $F_{2}$ and BC ${ }_{1}$ populations. The interspecific hybrids produced in this study were
attractive, fertile plants that are being used in further breeding to develop new cultivars.

Hydrangea was systematically described by McClintock (1957). She included 23 species with a disjunct distribution in both temperate and tropical regions of eastern Asia, eastern North America, and South America. Hydrangea macrophylla is the most popular of these species, and it is one of the most commercially important flowering shrubs grown worldwide. Hydrangea macrophylla is native to southern China and Japan and was cultivated there long before introduction into Europe in the $1800 \mathrm{~s}$ (McClintock, 1957; Wilson, 1923).

The genetic diversity among H. macrophylla cultivars is limited as a result of the

Received for publication 6 Apr. 2009. Accepted for publication 25 June 2009.

We thank Sandy Reed for help with flow cytometry.

${ }^{1}$ Current address: Plant Introductions, Inc., 2580 Antioch Church Road, Watkinsville, GA 30677.

${ }^{2}$ To whom reprint requests should be addressed; e-mail croback@uga.edu. restricted native distribution and multiple breeding programs that used the same taxa and had similar breeding goals (HaworthBooth, 1984; van Gelderen and van Gelderen, 2004). Most of the cultivars in existence today are derived from plants bred in the early 20th century through controlled crosses, open pollinations, or branch sports from introductions of wild-collected germplasm in the 19th and 20th centuries (Haworth-Booth, 1984; McClintock, 1957). Although over 1000 cultivars of $H$. macrophylla exist, many of them are similar in growth habit, floral characteristics, and disease susceptibility (Dirr, 2002). Recently, the introduction of remontant flowering or reblooming cultivars such as 'Bailmer' (Endless Summer ${ }^{\circledR}$ The Original) has increased the presence of hydrangeas in American commerce and gardens. New sources of genetic diversity are needed to develop cultivars with improved disease resistance, ease of production, and improved garden performance. Dan Hinkley, former owner of Heronswood Nursery, Bleddyn and Sue Wynn-Jones, owners of Crûg Farm Plants, and Scott McMahan, owner of McMahan's Nursery, have recently introduced new wildcollected H. macrophylla germplasm (personal communication).

Although interspecific and intergeneric hybridizations have been attempted within the Hydrangeaceae, most of the resultant hybrids were weak, sterile, or had reduced fertility and were of no commercial value. Hybridizations of $H$. macrophylla with $H$. anomala D. Don ssp. petiolaris (Siebold \& Zuccarini) McClintock (Haworth-Booth, 1984), H. arborescens Linnaeus (Kudo and Niimi, 1999; Reed, 2000), H. paniculata Siebold (Reed, 2004; Reed et al., 2001), H. quercifolia Bartram (Kudo et al., 2002; Reed, 2000), H. serrata (Thunberg) Seringe (Dirr, 2004; Zonneveld, 2004), and Dichroa febrifuga Loureiro (Jones et al., 2006; Kardos et al., 2006; Reed et al., 2008) have been reported. In addition, a preliminary report of hybridization between $H$. macrophylla and $H$. angustipetala has been published (Kardos et al., 2006), but the report lacks details on procedures and description of the hybrids. A hybrid with commercial potential was produced through ovule culture from the cross $H$. scandens ssp. chinensis to H. macrophylla, although the hybrid was sterile (Kudo et al., 2008). Unlike most of the interspecific hybrids, the intergeneric hybrids from $D$. febrifuga $\times H$. macrophylla are vigorous, fertile, and show potential for further breeding and/or introduction (Reed et al., 2008). Additional interspecific hybrids have been produced from $H$. arborescens 'Dardom' $\times$ $H$. involucrata Siebold (Jones and Reed, 2006) and $H$. involucrata $\times H$. aspera $\mathrm{D}$. Don (Dirr, 2004).

Rinehart et al. (2006) using microsatellite [simple sequence repeat (SSR)] markers showed a close relationship among H. macrophylla, H. scandens ssp. chinensis (H. angustipetala), and D. febrifuga. Jones et al. (2006), Kardos et al. (2006), and Reed et al. (2008) have produced $D$. febrifuga $\times H$. macrophylla hybrids, confirming the affinities revealed by the SSRs. Hydrangea macrophylla and $H$. angustipetala accessions were found to be diploid with $2 n=2 x=36$ chromosomes (Cerbah et al., 2001), although triploid $H$. macrophylla cultivars have been identified (Jones et al., 2007; Zonneveld, 2004). Zonneveld (2004) reported nuclear DNA contents of 4.54 and $4.76 \mathrm{pg}$ for $H$. macrophylla and $H$. angustipetala, respectively. The same ploidy level, similar nuclear DNA contents, and a high degree of relatedness between $H$. macrophylla and $H$. angustipetala, as indicated by SSR data, suggest the potential for successful interspecific hybridization.

Hydrangea angustipetala is a source of genetic diversity for traits such as powdery mildew resistance, early flowering, and narrow, evergreen foliage for incorporation into new hybrids with $H$. macrophylla cultivars (personal observation). Hydrangea macrophylla, native to southern China and Japan, characteristically possesses 10 to $20 \mathrm{~cm}$ long, 6 to $14 \mathrm{~cm}$ wide, coarsely toothed, matte 
green to lustrous dark green leaves, stout stems, and lacecap or mophead inflorescences 8 to $25 \mathrm{~cm}$ in diameter on 1 to $2 \mathrm{~m}$ high and wide plants. Flower color in H. macrophylla ranges from white to pink to purple to blue. Hydrangea angustipetala, native to Japan, China, and Taiwan, is deciduous to evergreen, flowers $\approx 4$ weeks earlier than $H$. macrophylla, and displays resistance to powdery mildew (personal observation). Mature plant size is $1.5 \mathrm{~m}$ high and wide with pubescent, dentate, shiny dark green leaves $\approx 6 \mathrm{~cm}$ long and $2.5 \mathrm{~cm}$ wide. Inflorescences are lacecap, $\approx 7.5 \mathrm{~cm}$ in diameter consisting of cream-yellow to white, fragrant fertile flowers surrounded by a few sterile flowers with three or four white sepals per flower. Flowers develop at each node, often the entire length of the stems. Variation exists within this species for growth habit, size of foliage, degree of foliage retention in winter, cold-hardiness, inflorescence size, and fragrance (personal observation). Hybridization between this species and $H$. macrophylla could result in hybrids with narrow, semievergreen to evergreen, lustrous foliage, improved powdery mildew resistance, early flowering, and fragrant flowers.

The taxonomy of $H$. angustipetala is debatable. Hydrangea angustipetala is listed as $H$. scandens ssp. angustipetala Mallet (Mallet, 1994), H. scandens ssp. chinensis (Maximowicz) McClintock (McClintock, 1957), and H. scandens ssp. chinensis f. angustipetala Hayata (Haworth-Booth, 1984; Zonneveld, 2004). Zonneveld (2004) suggests that $H$. angustipetala should be a separate species from $H$. scandens (L. f.) Seringe based on observations of heterogeneous DNA content in H. scandens (4.16 pg), H. scandens ssp. chinensis f. angustipetala (4.72 pg), and $H$. scandens ssp. chinensis f. liukiuensis (Nakai) McClintock (4.02 pg). Genome size differences are supported by SSR data, which also suggest that $H$. scandens ssp. chinensis f. angustipetala is genetically distinct from $H$. scandens ssp. chinensis f. liukiuensis (Rinehart et al., 2006). Therefore, the parental material used in this study is treated herein as $H$. angustipetala, although it could also be labeled $H$. scandens ssp. chinensis f. angustipetala.

The objective of this study was to hybridize, verify, and describe hybrids between $H$. macrophylla and $H$. angustipetala. The longterm goal of the research is to develop plants exhibiting a combination of desirable traits that have commercial value.

\section{Materials and Methods}

Pollinations. The following taxa were used in this study: H. macrophylla 'Lady in Red', a lacecap cultivar with red stems; Midnight Duchess ${ }^{\circledR}$, a lacecap cultivar with purple stems; and a single genotype of $H$. angustipetala. The genotype of $H$. angustipetala used was a seedling obtained in 2002 from Dan Hinkley, former owner of Heronswood Nursery, as $H$. angustipetala DJHT99116. This hydrangea was grown from seed wild-collected at $2100 \mathrm{~m}$ elevation in Taiwan. Flow cytometry analysis indicated that 'Lady in Red' and Midnight Duchess ${ }^{\circledR}$ are diploids, but the $H$. angustipetala plant has a larger genome size, indicative of a higher ploidy level (data not presented). All plants were grown outdoors under $45 \%$ shadecloth in 11.36-L containers filled with an amended pine bark substrate (Adkins and Dirr, 2003) and were overhead-irrigated as necessary.

Plants were brought into a heated greenhouse (day $24 \pm 2{ }^{\circ} \mathrm{C}$, night $18 \pm 2{ }^{\circ} \mathrm{C}$ ) in Jan. 2005. Hydrangea angustipetala developed flower buds $\approx 4$ weeks earlier than $H$. macrophylla. Therefore, $H$. angustipetala was placed into a walk-in cooler $\left(6 \pm 2{ }^{\circ} \mathrm{C}\right)$ for 4 weeks to synchronize flowering between the two species. Before crosses were initiated, any flowers that had already opened were removed, and all flowers used for hybridization were emasculated to prevent selfpollination. Controlled reciprocal pollinations were made in Apr. and May 2005 by removing dehisced anthers from the male parent and dabbing them directly onto the stigma of the female parent. Approximately 3 weeks after pollinations were completed, the plants were moved outside to a shade structure $(45 \%$ shade). The infructescences were allowed to develop fully on the plants and were collected into paper bags in Fall 2005 when they were dried under ambient conditions. The seeds were collected as the capsules dehisced.

Seeds were surface-sown in Nov. 2005 in flats filled with Fafard 3B substrate (Conrad Fafard, Inc., Agawam, MA) and placed under intermittent mist in a greenhouse (same temperatures as mentioned previously) until seedlings emerged. By Feb. 2006, one to two pairs of true leaves had formed, and seedlings were transplanted into individual $7.6 \times 7.6 \times$ $8.9-\mathrm{cm}$ containers. Seedlings were transplanted into 11.36-L containers filled with the same amended pine bark substrate cited previously and moved outside to a shade house (55\% shade) in May 2006 where they remained for the duration of this study. Outdoor evaluations were conducted at the UGA Durham Horticulture Research and Outreach Unit, Watkinsville, GA (lat. 335' $\mathrm{N}$; elev. = $232 \mathrm{~m}$, USDA cold hardiness zone 7).

Molecular analysis. Three seedlings that appeared to be hybrids and one seedling that resembled $H$. macrophylla were selected per cross along with the parents for hybrid verification using 12 SSR markers. Methods of Rinehart et al. (2006) were followed for DNA extraction, polymerase chain reaction amplification, and SSR analysis. Two-dimensional principal coordinate analysis (PCoA) plots were based on the allele sharing distance matrix (Gower, 1966; Jin and Chakraborty, 1994). Principal coordinate analysis was performed using NTSys software (Rohlf, 1992).

Morphological comparisons. Progeny and parents used for morphological comparisons were grown in 11.36-L containers in a shade house (55\% shade). In Spring 2007, 46 hybrids from the cross 'Lady in Red' $\times H$. angustipetala were randomly selected for morphological analysis. Leaf blade length and width were measured on one leaf per shoot and three shoots per hybrid. Means and ses of leaf blade length and width were calculated. Measurements were collected from one leaf per shoot and five shoots per parent; values were averaged for each parent. All leaves used for measurements were from the third node from the apex for progeny and parents. Stem pigmentation (red or green for 'Lady in Red' hybrids and purple or green for Midnight Duchess $^{\circledR}$ hybrids) was recorded for each hybrid. Inflorescence diameter was recorded for 28 'Lady in Red' $\times H$. angustipetala hybrids, 'Lady in Red', and H. angustipetala.

Pollen viability. Pollen viability was assessed using a fluorescein diacetate (FDA) staining procedure developed by HeslopHarrison and Heslop-Harrison (1970). Flowers were collected on the day of anthesis

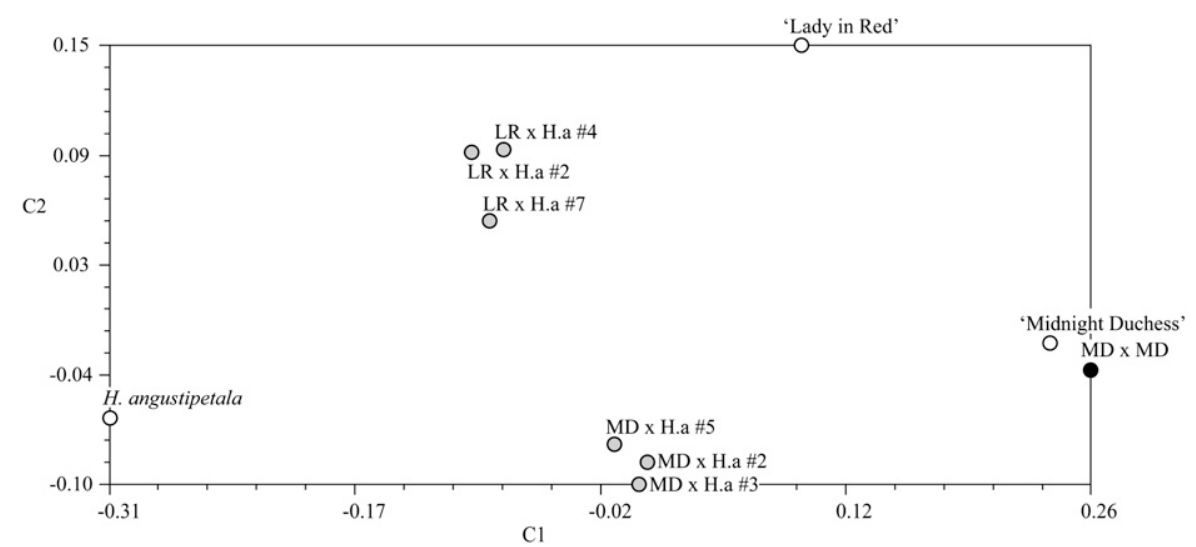

Fig. 1. Two-dimensional principal coordinate analysis plot based on allele sharing distances between samples representing the relationship between the interspecific hybrids and their parents. The hybrids (gray circles) clustered between their respective parents (open circles). X- and $\mathrm{Y}$-axes represent $71.8 \%$ and $28.2 \%$ of the genetic diversity, respectively. 'Lady in Red' $\times H$. angustipetala hybrids are labeled $\mathrm{LR} \times$ H.a \#2, \#4, and \#7. Midnight Duchess ${ }^{\circledR} \times H$. angustipetala hybrids are labeled MD $\times$ H.a \#2, \#3, and \#5. One plant suspected of being a self-fertilization of Midnight Duchess ${ }^{\circledR}$ is labeled MD $\times$ MD (black circle). 
from five randomly chosen hybrids per cross, 'Lady in Red', Midnight Duchess ${ }^{\circledR}$, and $H$. angustipetala. Pollen from newly dehisced anthers was transferred to a microscope slide, mixed with a drop of FDA-sucrose solution, and covered with a coverslip. After $10 \mathrm{~min}$, the slides were examined under a Zeiss fluorescent microscope with a Zeiss 09 Blue filter (Carl Zeiss MicroImaging, Inc., Thornwood, NY) and individual pollen grains scored as fluorescent (viable) or nonfluorescent (nonviable). Three fields of 100 pollen grains each were counted per hybrid and parent and the mean number of fluorescent grains calculated for each genotype.

\section{Results and Discussion}

Pollinations. Viable seeds were produced from interspecific crosses, but only when $H$. macrophylla was used as the female and $H$. angustipetala was used as the male. The two plants of $H$. angustipetala available for hybridization were small and produced only two inflorescences per plant. All the pollen produced by $H$. angustipetala was collected for hybridization, and in the process, it is likely the inflorescences were damaged. Physical damage to the $H$. angustipetala flowers leading to abscission is the most likely explanation for the difference in reciprocal seed set. This hypothesis is further supported by the production of viable seed and seedlings from reciprocal crosses between $H$. macrophylla and H. luteovenosa Koidzumi (Kardos, unpublished data). Hydrangea luteovenosa is closely related to $H$. angustipetala, and both species are often listed as subspecies of $H$. scandens (L.) Ser. (Dirr, 2004; McClintock, 1957).

Both 'Lady in Red' and Midnight Duchess $^{\circledR}$ were crossed successfully with $H$. angustipetala. 'Lady in Red' $\times H$. angustipetala produced 189 seedlings, whereas Midnight Duchess ${ }^{\circledR} \times H$. angustipetala produced 61 seedlings. All seedlings grew vigorously in the greenhouse. After the seedlings were transplanted into 11.36 -L containers and moved outside, they continued to grow vigorously, and by Fall 2006, many of the seedlings had grown to $0.6 \mathrm{~m}$ tall $\times 0.6 \mathrm{~m}$ wide or larger. 'Lady in Red' $\times H$. angustipetala produced 187 seedlings with intermediate morphological traits and two seedlings that resembled the $H$. macrophylla parent with no obvious influence of $H$. angustipetala on either leaf morphology or growth habit. Midnight Duchess ${ }^{\circledR} \times H$. angustipetala produced 47 seedlings with intermediate morphological traits and 14 seedlings that resembled the H. macrophylla parent. The seedlings that resembled only their $H$. macrophylla parent likely resulted from self-pollination, because some self-pollen was apparently present on a few flowers within an inflorescence before emasculation and SSR data are consistent with self-pollination.

Molecular analysis. Twelve SSR markers were used to verify interspecific hybridizations by comparing allele size variation between parents and hybrid progeny. These same SSR loci are highly polymorphic and were used by Rinehart et al. (2006) to distinguish between hydrangea species and estimate genetic diversity within and between groups of related hydrangea. Speciesspecific allele sizes were identified for these SSR loci to create a molecular key of hydrangea species, which was used for interspecific hybrid identification between the species used here (Rinehart et al., 2006). A twodimensional scatterplot from a PCoA demonstrates the relationship of the hybrids to their respective parents (Fig. 1). One hundred percent of the genetic diversity in the distance matrix is explained by this plot, which is drawn proportional. The three hybrids for each cross cluster intermediate to their respective parents. Hybrids cluster in two groups representing the difference between H. macrophylla cultivar contributions. The single seedling that resembled Midnight Duchess ${ }^{\circledR}$ clustered with Midnight Duchess ${ }^{\circledR}$ on the H. macrophylla side of the plot. This seedling lacked $H$. angustipetela-specific allele sizes, which confirm that it is not an interspecific hybrid. Rather, allele size variation was reduced and consistent with selfpollination of Midnight Duchess ${ }^{\circledR}$. All other hybrids produced allele sizes consistent with both expected parents, including speciesspecific sizes that confirm interspecific hybridization between $H$. angustipetala and H. macrophylla.
Morphological comparisons. Leaf blades of $H$. angustipetala were shorter and considerably narrower than those of 'Lady in Red' (Table 1). Mean leaf blade length and width were intermediate in the 'Lady in Red' $\times H$. angustipetala hybrids. The hybrid population involving 'Lady in Red' segregated 122 plants with red and 65 plants with green stem pigmentation. The hybrid population involving Midnight Duchess ${ }^{\circledR}$ segregated 22 plants with purple and 25 plants with green stem pigmentation. A 1:1 ratio for purple or green stems supports previous data, which indicated purple stem pigmentation is controlled by a single dominant allele (Kardos, 2008). The hybrids with red (Fig. 2B) or purple (Fig. 2D) stem pigmentation were more ornamental than the green-stemmed plants. The hybrids were well-branched, multistemmed

Table 1. Leaf measurements of H. macrophylla 'Lady in Red', $H$. angustipetala, and their hybrids. ${ }^{2}$

\begin{tabular}{lcc}
\hline Taxon & $\begin{array}{c}\text { Mean blade } \\
\text { length }(\mathrm{cm})^{\mathrm{y}}\end{array}$ & $\begin{array}{c}\text { Mean blade } \\
\text { width }(\mathrm{cm})\end{array}$ \\
\hline $\begin{array}{l}\text { Lady in Red } \\
\text { Lady in Red } \times H .\end{array}$ & 6.5 & 7.9 \\
$\quad$ angustipetala & $10.8 \pm 0.2$ & $3.3 \pm 0.1$ \\
H. angustipetala & 7.6 & 1.9 \\
\hline
\end{tabular}

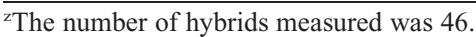

${ }^{\mathrm{y}}$ Reported as the mean for parents and mean $\pm \mathrm{SE}$ for the hybrids.

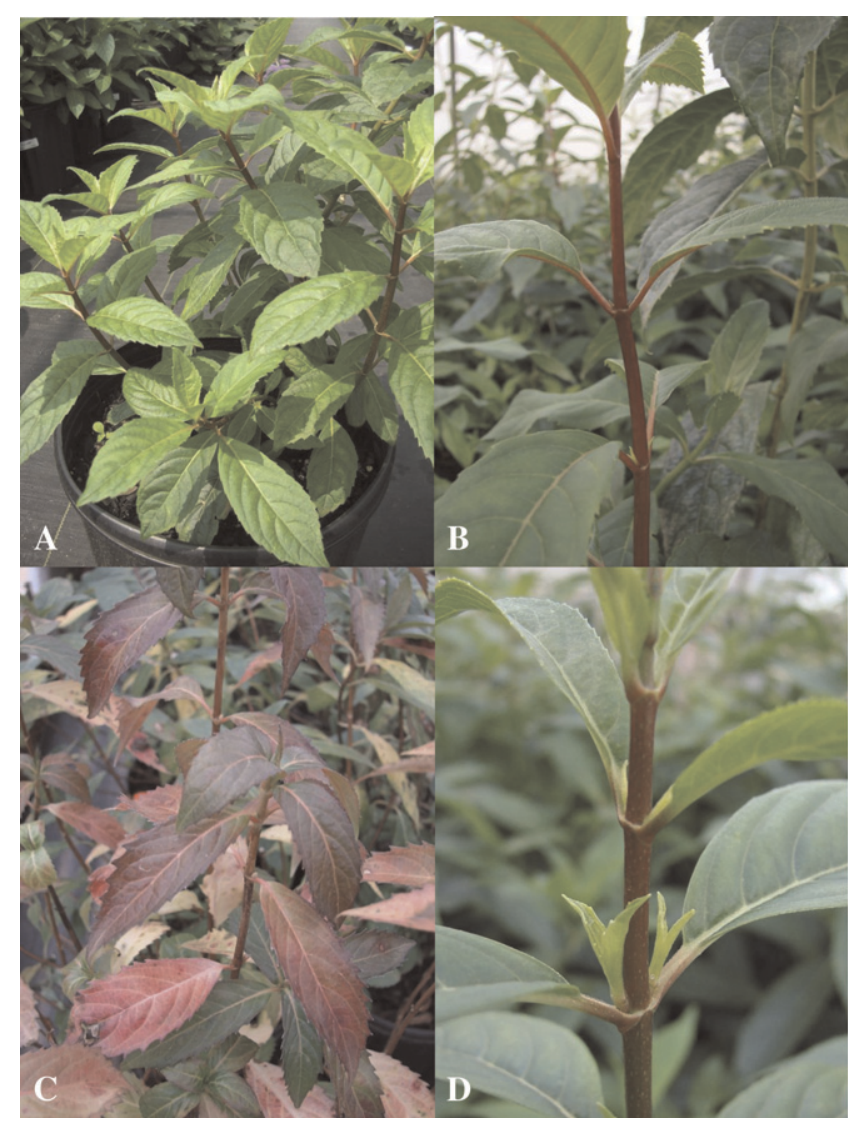

Fig. 2. (A) Growth habit, (B) red-pigmented stem, (C) fall color from 'Lady in Red' $\times H$. angustipetala hybrids, and (D) pigmented stem from Midnight Duchess ${ }^{\circledR} \times H$. angustipetala hybrid. All seedlings were in their first growing season. 


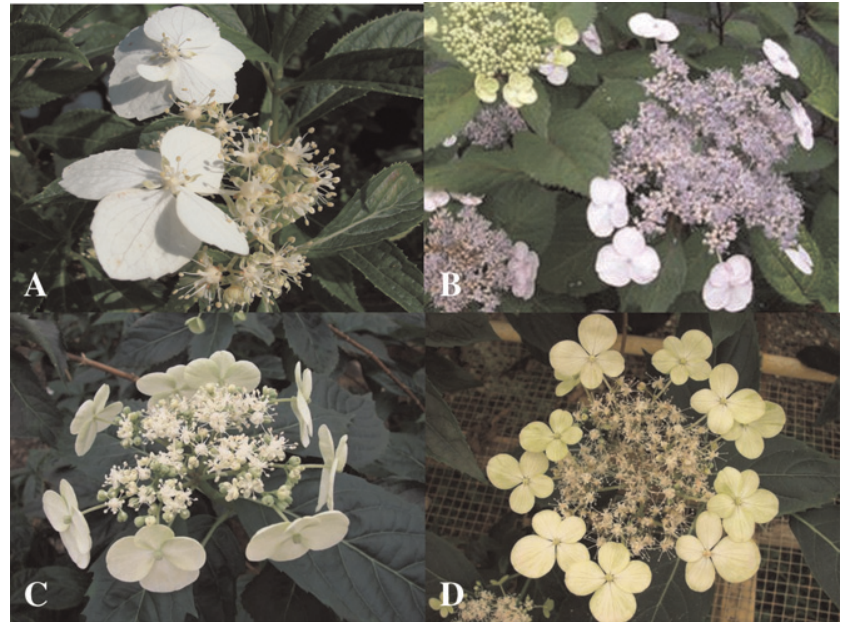

Fig. 3. Inflorescences from (A) H. angustipetala, (B) 'Lady in Red', and (C-D) 'Lady in Red' $\times H$. angustipetala hybrids.

plants even without pruning (Fig. 2A). Winter leaf retention of the hybrids ranged from deciduous to semievergreen with some hybrids developing red to purple fall color (Fig. 2C).

Hybrids from both crosses flowered in the greenhouse during April and May 2007. All inflorescences were lacecap, as were the parents, consisting of central fertile flowers surrounded by a ring of showy sepals (Fig. 3A-D). Most inflorescences emerged creamy white and aged to white or pale green. Three hybrids from 'Lady in Red' $\times H$. angustipetala possessed inflorescences that emerged creamy white but aged to pale pink. Because $H$. angustipetala produces only white inflorescences, this pink coloration must be from 'Lady in Red'. Some flowers possessed a faint fragrance, a trait that is typically absent from $H$. macrophylla. Inflorescence size for the 'Lady in Red' $\times H$. angustipetala hybrids ranged from 3.6 to $16.2 \mathrm{~cm}$ in diameter with a mean of $9.0 \mathrm{~cm}$. 'Lady in Red' and $H$. angustipetala had inflorescences $\approx 11.4$ and $7.5 \mathrm{~cm}$ in diameter, respectively. Hybrid inflorescences more closely resembled those of $H$. angustipetala in color and overall appearance.

Pollen viability. Pollen viability was estimated in the hybrids and parents by FDA staining. 'Lady in Red', Midnight Duchess ${ }^{\circledR}$, and $H$. angustipetala had $62 \%, 58 \%$, and $79 \%$ stainable pollen, respectively. Stainable pollen ranged from $29 \%$ to $56 \%$ for the 'Lady in Red' $\times H$. angustipetala hybrids and from $43 \%$ to $52 \%$ for the Midnight Duchess ${ }^{\circledR} \times H$. angustipetala hybrids. Although pollen viability was reduced in the hybrids, it indicated they were male-fertile. Male and female fertility of the hybrids was confirmed by using some of them in controlled crosses, which resulted in production of $\mathrm{F}_{2}$ and $\mathrm{BC}_{1}$ progeny. Jones and Reed (2006) found male fertility to be much lower, $1 \%$ stainable pollen, in the interspecific hybrid $H$. arborescens 'Dardom' $\times H$. involucrata. Male fertility of intergeneric hybrids between $D$. febrifuga and $H$. macrophylla ranged from $5 \%$ to $62 \%$ stainable pollen in one study (Reed et al., 2008) and from $0 \%$ to $73 \%$ stainable pollen in another study (Kardos, unpublished data).

This study demonstrated the close relationship between $H$. macrophylla and $H$. angustipetala, as reported in a recent phylogenetic study (Rinehart et al., 2006). The interspecific hybrids were attractive plants that, on average, were intermediate to the parents for traits such as inflorescence size, leaf shape and size, and degree of foliage retention in winter. The hybrids were fertile and selected progeny are being incorporated into a $H$. macrophylla breeding program.

\section{Literature Cited}

Adkins, J.A. and M.A. Dirr. 2003. Remontant flowering potential of ten Hydrangea macrophylla (Thunb.) Ser. cultivars. HortScience 38:1337-1340.

Cerbah, M., E. Mortreau, S. Brown, S. SiljakYakovlev, H. Bertrand, and C. Lambert. 2001. Genome size variation and species relationships in the genus Hydrangea. Theor. Appl.

Dirr, M.A. 2002. In search of a perfect Hydrangea. Nursery Mgt. Production 18:16-17, 95-96.

Dirr, M.A. 2004. Hydrangeas for American gardens. Timber Press, Portland, OR.

Gower, J.C. 1966. Some distance properties of latent root and vector methods used in multivariate analysis. Biometrica 53:325-338.

Haworth-Booth, M. 1984. The hydrangeas. 5th Ed. Constable and Company, London, UK.

Heslop-Harrison, J. and Y. Heslop-Harrison. 1970. Evaluation of pollen viability by enzymatically induced fluorescence; intracellular hydrolysis of fluorescein diacetate. Stain Technol. $45: 115-120$

Jin, L. and R. Chakraborty. 1994. Estimation of genetic distance and coefficient of gene diversity from single-probe multilocus DNA fingerprinting data. Mol. Biol. Evol. 11:120-127.

Jones, K.D. and S.M. Reed. 2006. Production and verification of Hydrangea arborescens 'DarGenet. 103:45-51. dom' $\times H$. involucrata hybrids. HortScience 41:564-566.

Jones, K.D., S.M. Reed, and T.A. Rinehart. 2006 Wide crosses in the Hydrangeaceae: Dichroa febrifuga $\times$ Hydrangea macrophylla. Proc. Southern Nursery Assn. Res. Conf. 51:577-579.

Jones, K.D., S.M. Reed, and T.A. Rinehart. 2007. Analysis of ploidy level and its effects on guard cell length, pollen diameter and fertility in Hydrangea macrophylla. HortScience 42: 483-488.

Kardos, J.H. 2008. Interspecific and intergeneric hybridization involving Hydrangea macrophylla (Thunberg) Seringe and inheritance studies in H. macrophylla. PhD Diss., University of Georgia.

Kardos, J.H., C.D. Robacker, M.A. Dirr, and T.A Rinehart. 2006. Production and verification of hybrids from Hydrangea macrophylla $\times H$. angustipetala and $H$. macrophylla $\times$ Dichroa febrifuga. Proc. Southern Nursery Assn. Res. Conf. 51:570-572.

Kudo, N., Y. Kimura, and Y. Niimi. 2002. Production of interspecific hybrid plants by crossing Hydrangea macrophylla f. hortensia (Lam.) Rehd. and H. quercifolia Bartr. through ovule culture. Hort. Res. Japan 1:9-12.

Kudo, N., T. Matsui, and T. Okada. 2008. A novel interspecific hybrid plant between Hydrangea scandens ssp. chinensis and H. macrophylla via ovule culture. Plant Biotechnol. 25:529-533.

Kudo, N. and Y. Niimi. 1999. Production of interspecific hybrids between Hydrangea macrophylla f. hortensia (Lam.) Rehd. and H. arborescens L. J. Jpn. Soc. Hort. Sci. 68: 428-439.

Mallet, C. 1994. Hydrangeas: Species and cultivars. Vol. 2. Centre d'Art Floral, Varengeville, France.

McClintock, E. 1957. A monograph of the genus Hydrangea. Proc. Calif. Acad. Sci. 14:147-256.

Reed, S.M. 2000. Compatibility studies in Hydrangea. J. Environ. Hort. 18:29-33.

Reed, S.M. 2004. Floral characteristics of a Hydrangea macrophylla $\times H$. paniculata hybrid. Proc. Southern Nursery Assn. Res. Conf. 49: $580-582$.

Reed, S.M., K.D. Jones, and T.A. Rinehart. 2008 Production and characterization of intergeneric hybrids between Dichroa febrifuga and Hydrangea macrophylla. J. Amer. Soc. Hort. Sci. 133:84-91.

Reed, S.M., G.L. Riedel, and M.R. Pooler. 2001. Verification and establishment of Hydrangea macrophylla 'Kardinal' $\times H$. paniculata 'Brussels Lace' interspecific hybrids. J. Environ. Hort. 19:85-88.

Rinehart, T.A., B.E. Scheffler, and S.M. Reed. 2006. Genetic diversity estimates for the genus Hydrangea and development of a molecular key based on SSR. J. Amer. Soc. Hort. Sci. 131:787-797.

Rohlf, F.J. 1992. NTSYS-pc numerical taxonomy and multivariate analysis system. Version 1.70. Exeter Software, Setauket, NY

van Gelderen, C.J. and D.M. van Gelderen. 2004. Encyclopedia of hydrangeas. Timber Press, Portland, OR.

Wilson, E.H. 1923. The hortensias Hydrangea macrophylla DC and Hydrangea serrata DC. J. Arnold Arbor. 4:233-246.

Zonneveld, B.J.M. 2004. Genome size in Hydrangea. In: Van Gelderen, C.J. and D.M. van Gelderen (eds.). Encyclopedia of hydrangeas. Timber Press, Portland, OR. 